\title{
Application of Building Information Modeling (BIM) in the Malaysian Construction Industry: A Story of the First Government Project
}

\author{
Aryani Ahmad Latiffi ${ }^{1, a}$, Suzila Mohd ${ }^{2, b}$ and Juliana Brahim ${ }^{3, c}$ \\ ${ }^{1,2,3}$ Department of Construction Management, Faculty of Technology Management and Business, \\ Universiti Tun Hussein Onn Malaysia (UTHM), 86400 Parit Raja, Batu Pahat, Johor, Malaysia \\ aaryani@uthm.edu.my, bsuzilamohd@gmail.com, ’ju_brahim@yahoo.com
}

\begin{abstract}
Keywords: Application, Building Information Modeling (BIM), Construction Industry, Government Project, Malaysia.
\end{abstract}

\begin{abstract}
Building Information Modeling (BIM) is currently being used by the architecture, engineering and construction (AEC) industry in Malaysia. It has been introduced by the Director of Public Works Department (PWD) in 2007 to reduce construction costs and avoid design problems. BIM utilization in construction can detect any clash analysis during the design stage, improves efficiency of project scheduling, reduce costs and ensure high quality of the project as well as facilitate communication among construction players. Since it has been introduced by the PWD, several projects have been constructed and being constructed using BIM and one of the project is The National Cancer Institute (NCI). The project is owned by the Malaysian government. This paper discusses the application of BIM in the project, the first project launched by the Malaysian government. A literature review was conducted to explore previous BIM studies on the history of BIM, benefits and importance, barriers and challenges as well as existing BIM projects in the Malaysian construction industry. Furthermore, semi-structured interviews were carried out with the client, consultant and contractor involved in the project. The interviews results reveal necessities and benefits of implementing BIM in completing the project. BIM is necessary for construction because its implementation can increase project quality. It is useful in assisting construction players to complete projects successfully. The results provide clear evidence of the effectiveness of implementing BIM in government projects. This paper can serve as a reference for critical studies of developing a strategy approach model for BIM implementation in the Malaysian construction industry.
\end{abstract}

\section{Introduction}

Building Information Modeling (BIM) is a new approach to manage construction project life cycle activities, which are project design, construction and facility management [1]. The use of BIM in managing construction project life cycle has been in place since 1970 and its implementation has become more widespread in the construction industry for producing data-rich models of buildings and structures $[2,3,4,5]$. BIM had been used in many countries such as America, Australia, Denmark, Norway, Finland and Singapore $[2,4,6]$.

In Malaysia, BIM had been introduced by the Public Works Department (PWD) since early 2007 [4,7]. The exploration of BIM by PWD had been supported by the establishment of a BIM Committee within PWD. The purpose was to identify a suitable BIM platform that could be used by PWD. The Committee proposed to use Autodesk as one of the BIM tools [8]. The use of the tool was proposed through the Information Technology Department. Subsequently, by the end of 2010, installation of the BIM tool started in PWD, followed by the training in using the tool in early 2011 [7].

Moreover, BIM Unit Project was established in May 2012, which consists of architects, structural engineers, mechanical and electrical (M\&E) engineers as well as quantity surveyors. The purpose is to produce a families' component, which is Revit Families for two pilot projects [7]. The pilot projects are Type 5 Clinic (KK5) Sri Jaya Maran, Pahang and Administration Complex of Suruhanjaya Pencegah Rasuah Malaysia (SPRM) Shah Alam, Selangor [4,7]. 
The implementation of BIM in the construction industry has been encouraged by the Malaysian Government to facilitate achievement of the vision of the CIDB Master Plan as well as the nation's 2020 vision through an increase in key performance indicators (KPIs) and productivity [9, 10, 11]. To date, the Malaysian construction industry faces huge challenges in fulfilling the community demands for increasing productivity, quality and value [12]. Thus, the best construction practices program model for the Malaysian construction industry involves information technology (IT) programs and tools $[11,13,14]$.

BIM is often used to represent IT in construction [15], and it had been seen as a potential solution to the problems faced in the current construction industry scenario. BIM is viewed as an integrated process that allows construction players to explore a project's key physical and functional characteristics digitally before the construction starts [16]. BIM is also seen as a collaboration among different construction players at different phases of the life cycle of a facility to insert, extract, update or modify information in the model to support and reflect the roles of those stakeholders [11,17]. BIM can enhance the planning process, design and quality of construction projects [4]. The benefits of BIM to construction players cover many aspects, which include the following, design, budget, communication, documentation, and scheduling [4].

The ultimate aim of promoting the use of BIM in construction projects among construction players is to improve the quality of the construction projects in Malaysia. BIM had been proven to be a technology that can assist clients to avoid delay in projects and cost overruns as well as improve communication among construction players in projects [4]. It is important to know the application of BIM in the project as it can be a lesson learnt to others to implement BIM and increase the quality of project.

The next part of this paper is on the first government project using BIM, which is the National Cancer Institute (NCI) project. Before that, the methodology of the research is explored.

\section{Methodology}

A review was conducted on the past literature, to obtain information related to BIM such as on the history and definition, benefits, and purpose of BIM implementation in construction projects. Various sources were reviewed, such as books, journal articles, international conference papers and materials available on the internet.

Moreover, semi-structured interviews were used as a method to obtain data from respondents on their BIM practices. The interviews were conducted in a face-to-face setting. The respondents were the client of NCI, consultant and contractor for the project. The NCI project is located in Putrajaya, the city that houses many federal government buildings in Malaysia.

All data obtained from the interviews were analyzed using content analysis. The content analysis viewed data presented as texts, images, and expressions [18].

The following part discusses the results and findings from the interviews.

\section{Results and Findings}

This part discusses the results and findings from the interviews. This part has been divided into four (4) sections as follows:

Overview of the National Cancer Institute (NCI), Malaysia. The National Cancer Institute (NCI) is the first government project using BIM in Malaysia, which is also a pilot project of the government. The project worth of RM 690 million is set to provide comprehensive care to patients, and it has been in full operation since $31^{\text {st }}$ August 2013. The institute is also a national referral center of excellence for cancer treatment in Malaysia [19].

Minister of Health, Dr Subramaniam said, NCI would be the pioneer in the country to have a comprehensive information and communication technology (ICT) system or Total Hospital System (THIS) with the element of the Oncology Information System (OIS). THIS can be integrated online with two other nearby hospitals, Putrajaya and Serdang, to ease management of patients. The 
construction of the NCI was the brainchild of the late Datin Seri Endon Mahmood, the wife of former Prime Minister Tun Abdullah Ahmad Badawi in 2004. She died of breast cancer a year later [20].

The design concept introduced by the consultant to this project is to have a hospital focusing on providing patients with specific health and medical care supported by state-of-the-art specialized diagnostic and treatment facilities. It is also designed to create a cheerful, non-intimidating, userfriendly and functional ambience. It has an interesting architectural interior design and landscaping to create an ideal environment for healing and recuperation. The details of the project are shown in Table 1.

Table 1, The National Cancer Institute (NCI) Project

\begin{tabular}{|c|l|l|}
\hline No. & Items & Details \\
\hline 1 & Client & Ministry of Health of Malaysia (MOH) \\
\hline 2 & Consultant & Perunding Alam Bina Sdn. Bhd. \\
\hline 3 & BIM Consultant & Precision Design Solution (M) Sdn. Bhd. \\
\hline 4 & Turnkey Contractor & Kiara Teratai Sdn. Bhd. \\
\hline 5 & Contract Period & 36 months \\
\hline 6 & Site Possession & $1^{\text {st }}$ September 2010 \\
\hline 7 & Completion Date & $31^{\text {st }}$ August 2013 \\
\hline 8 & Total Site Area & 4.31 ha $(10.65$ acres $)$ \\
\hline 9 & Total Gross Floor Area & 75,555 square meters $\left(\mathrm{m}^{2}\right)$ \\
\hline 10 & BIM tools & Autodesk Revit (Architecture, Structure, M\&E), Naviswork \\
\hline
\end{tabular}

Based on Table 1, the client of the project is the Ministry of Health of Malaysia (MOH) and other project members consist project consultant, BIM consultant as the specialist on BIM for the project and contractor for the project. The indicators of R1, R2 and R3 will be used in this part to represent the respondents. $\mathrm{R} 1$ represents client of the project, $\mathrm{R} 2$ for BIM consultant and R3 for the contractor of the project. Figure 1 shows the pictures of NCI.

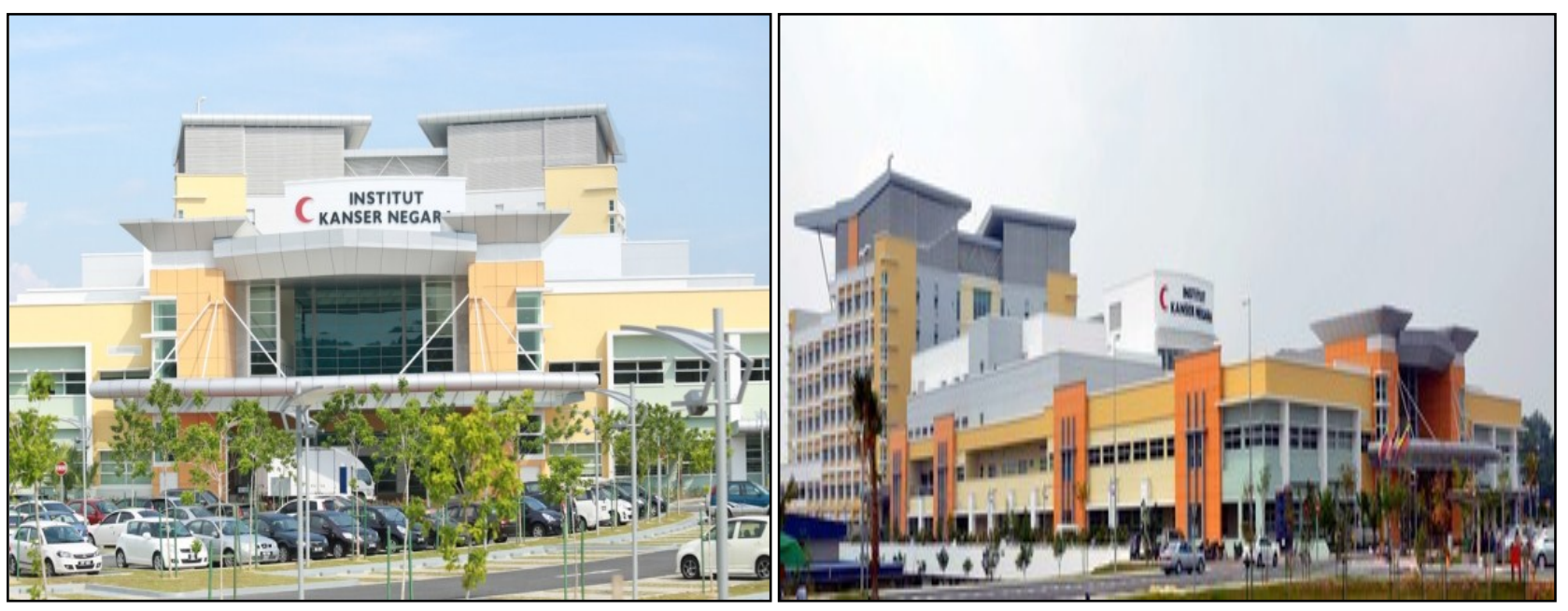

Fig. 1, The NCI project [21]

Understanding of BIM. All respondents agree that BIM can be defined as a combination of models and information that is used to analyze a building prior to the construction process. They understand that BIM can be used to minimize waste in terms of time and cost, with the purpose of increasing project quality. Table 2 shows understanding of the respondents on BIM. 
Table 2. Definitions of BIM

\begin{tabular}{|c|c|c|c|l|}
\hline Respondent & Position & $\begin{array}{c}\text { Experience in } \\
\text { Construction }\end{array}$ & $\begin{array}{c}\text { Experience } \\
\text { in BIM }\end{array}$ & Definition of BIM \\
\hline R1 & Client & 15 years & 3 years & $\begin{array}{l}\text { Information and design that is combined so that the } \\
\text { design can be visualized and analyzed. }\end{array}$ \\
\hline R2 & $\begin{array}{c}\text { BIM } \\
\text { Consultant }\end{array}$ & 15 years & 3 years & $\begin{array}{l}\text { Combination of 3-dimensional (3D) model and } \\
\text { information. It is used to construct and analyze a } \\
\text { building prior to construction. }\end{array}$ \\
\hline R3 & Contractor & 25 years & 3 years & $\begin{array}{l}\text { Combination of various types of construction } \\
\text { information in one secular model. It contains } \\
\text { information about the structure, design and take-off. }\end{array}$ \\
\hline
\end{tabular}

According to R1, the main objectives of BIM usage in the NCI project are to improve communication and collaboration among construction players, minimize rework and design changes due to uncoordinated design, ensure installation quality, verify and monitor work program and work progress through 4-dimensional (4D) model, and populate or capture information as much as possible to provide facility management $(\mathrm{FM})$ purposes.

Benefits of BIM for the Project. All respondents agree that BIM is used to avoid delays in construction and construction cost overruns as well as contribute to better quality of the end product. Implementation of BIM has various effects on the project. The major effects are the minimization of waste that consists of reduced time required to complete the project and saving of construction costs; besides, it improves the quality of the project required by a client. The implementation of BIM has contributed several benefits to the NCI project. One of the benefits of implementing BIM in the project is related to the duration of construction project. R1 mentioned that the NCI project has been completed 2 weeks ahead of schedule.

Other benefits of BIM implementation in the project is clash detection. Clash detection can be done before the construction starts. All respondents agreed that clash detection can be made prior to the construction stage. They added that detection of clashes can be done in the early stage of a construction project. According to R1 and R2, there are 1800 clashes were found in the NCI project design and have been resolved during the planning stage, and this is not possible in projects without BIM.

Apart from that, other benefits of BIM are its ability to resolve fabricator issue, and provision of clearer 3D visualization of project design so that any changes to the project can be made easily. BIM visualizes the building model in 3D, which provides a clear design and structure of the building. Besides, all respondents also agree that BIM is very helpful not only to architects and structural engineers, but also in carrying out the mechanical and electrical (M\&E) works. This is because the clashes can be detected at an earlier stage of the construction projects.

Barriers and Challenges to Implementing BIM. There are also barriers and challenges of implementing BIM for projects. All respondents agree that adoption of BIM can be time consuming because of the transition to a new technology. Moreover, the initial costs to adopt BIM technology and hardware are high, and only large organizations can afford to own the technology. Furthermore, $\mathrm{R} 3$ explains that an organization needs to hire new workers who have the skills and knowledge in BIM to implement it in the organization. These changes require reallocation of costs for the organization. The number of BIM experts is very low in the Malaysian construction industry and this factor has an effect on the cost of a construction project. Organizations also have to give training to their workers or staff to educate them about the technology. The learning process requires time and training which incur additional costs for the organizations concern. 


\section{Conclusion and Further Works}

The Malaysian government is aware of the benefits offered by BIM to improve the quality of projects in the construction industry. The government has made several efforts to promote BIM by highlighting it through the platform of roundtable discussion with construction players, forums and seminars as well as providing the latest information through portal. The government's initiatives have contributed to project developments using BIM in the construction industry. In 2010, the first government project using BIM was planned and the project is known as the NCI project, which was completed in August 2013. The project shows the benefits gained from using BIM, which are reflected in the minimization of waste in terms of time and cost, leading to improve quality of the project. With the use of BIM for designing the project, clashes could be detected before the construction process began. Hence, no rework for the project was needed, eliminating any additional construction costs. The success of the project has led to more government projects using BIM.

BIM implementation in the Malaysian construction industry can be increased through government initiatives, proof of successful projects using BIM and construction players' awareness of the benefits of BIM. Future studies can be carried out on other BIM projects in Malaysia involving the government and private sectors. Based on the findings, an approach can be recommended to assist construction players in using this technology for construction projects.

\section{Acknowledgement}

The authors would like to thank the Ministry of Education of Malaysia (MOE), and the Office of Research, Innovation, Commercialization and Consultancy (ORICC), UTHM, for supporting this research under the Exploratory Research Grant Scheme (ERGS), Vote No. E029.

\section{References}

[1] C. Eastman, P. Teicholz, R. Sacks and K. Liston, BIM Handbook: A Guide to Building Information Modeling for Owners, Managers, Designers, Engineers and Constructions, John Wiley and Son Inc, New Jersey, 2011.

[2] Wong, A.K.D., Wong, F.K.W. and Nadeem, A. Government Roles in Implementing Building Information Modelling Systems. Construction Innovation, 1(1), (2009) 61-76.

[3] M. Dobelis, Drawback of BIM Concept Adoption, The 12th International Conference on Engineering Graphics BALTGRAF, June 5-7, 2013, Riga, Latvia (2013).

[4] A. Ahmad-Latiffi, S. Mohd, N. Kasim and S. M. Fathi, "Building Information Modeling (BIM) Application in Malaysian Construction Industry,"International Journal of Construction Engineering and Management 2(4A), (2013) 1-6.

[5] R. Barati, A. Charehzehi and C. N. Preece, Enhancing Planning And Schedulling Program by Using Benefits of BIM-Based Application, Civil and Environmental Research, 3(5), (2013).

[6] C. Furneaux and R. Kivit, BIM: Implication for Government, CRC for Construction Innovation, Brisbane, Australia. Net Ptd. Ltd., (2008) 10-31.

[7] Jabatan Kerja Raya (PWD), Unit Building Information Modelling (BIM). Information on https://www.jkr.gov.my/prokom/index.php?option=com_content\&view=article\&id=84\&Itemid=43 $5 \&$ lang $=\mathrm{ms}$.

[8] A. Ahmad-Latiffi and S. Mohd, "Building Information Modeling (BIM) Technology in the Sultan Ibrahim Hall of UTHM," 2014 IEEE Colloquium on Humanities, Science and Engineering, (2013) 221-226.

[9] A. R. Ibrahim, M. H. Roy, Z. Ahmed and G. Imtiaz, An Investigation of the Status of the Malaysian Construction Industry, An International Journal, 17(2), (2010) 294-308. 
[10] T. H. Nguyen, T. Shebab and Z. Gou, Evaluating Sustainability of Architectural Designs Using Building Information Modelling, The Open Construction and Building Technology Journal, (4) (2010) 1-8.

[11] K. N. Ali and W. I. Enegbuma, Hypothesis Analysis of Building Information Modelling Penetration in Malaysian Construction Industry. Information on http://www.conference.net.au/cibwbc13/papers/cibwbc2013_submission_224.pdf.

[12] Z. Zahrizan, N. M. Ali, A. T. Haron, A. Marshal-Ponting and Z. A. Hamid, Exploring the Adoption of Building Information Modelling (BIM) in the Malaysian Construction Industry: A Qualitative Approach, International Journal of Research in Engineering and Technology, (2) (2013) 384-395.

[13] K. A. Mohamad-Kamar and Z. Abd-Hamid, Supply Chain Strategy for Construction in Adopting Industrialised Building System (IBS), Australian Journal of Basic and Applied Science, 5(12), (2011) 2552-2557.

[14] R. Sebastian, Changing Roles of the Clients, Architects and Contractors Through BIM, Engineering Construction and Architectural Management, 18(2), (2011) 176-187.

[15] Y. Jung and M. Joo, Building Information Modelling (BIM) Framework for Practical Implementation, Automation in Construction, (20) (2011) 126-133.

[16] Construction Research Institute of Malaysia (CREAM), (2012), A Case Study of BIM Implementation in Malaysia. Information on http://www.myconstructionresearch.com/index. $\mathrm{php} /$ publication /integrated-design-delivery solution/file/12-bim-implementation-in-malaysia.

[17] D. Smith and A. Edgar, Building Information Modelling. Information on http://www.wbdg.org/bim/bim.php.

[18] K. Krippendorff, Content Analysis: An Introduction to its Methodology, Sage Publications Inc., California. 2004.

[19] News Straits Times (NST). National Cancer Institute Ready by Aug 31, 2013. Information on http://www.nst.com.my.

[20] The Sun Daily (TSD). National Cancer Institute To be Operational In A Month: Subra. Information on http://www.thesundaily.my/node.

[21] Utusan Online, Institut Kanser Negara Buka 2 Bulan Lagi: Thomas Chong. Information on http://www.utusan.com.my/utusan/Dalam_Negeri/20130919/dn_19/Institut-Kanser-Negara-dibuka2-bulan-lagi. 